\title{
Usage of telecommunication technology in perpetration of sexual assault- A study conducted on reported victims in a Tertiary Medical College Hospital OCC \\ Farooqui I ${ }^{1}$,Islam $\mathrm{MS}^{2}$, Chowdhury $\mathrm{RA}^{3}$, Hasan $\mathrm{ATMH}^{4}$
}

\begin{abstract}
The sexual assaults and its consequences are increasing along with socioeconomic development of the country. Rise of modern communication technology add fuel to the flame. This descriptive crosssectional study aimed to evaluate the role of communication technology in sexual assaults in Bangladesh. There were 87 victims included in this study. All were female of 6 years to 40 years of age, mean age was $15.67( \pm 6.69)$ year. Most of the victims were below 20 years of age and came from low income families. About $76 \%$ mobile used were smart phone. Among them $46 \%$ were owned by the victims herself, $26 \%$ gifted by the assailants to the victims. Talking through mobile (37\%) was the main communication route between the assailants and the victims; followed by direct verbal (31\%), mixed verbal and mobile talking (26\%) and others (6\%). Regarding methods of communication, they only talk in $42 \%$ cases and $36 \%$ cases used mixed method (talking, SMS and video chatting). The assailant paid all the costs in $62 \%$ cases. Mobile phone came as a blessing in communication, but inchoate use makes it a curse to our society. Parents should be cautious about their children's mobile usage (especially smart phone) daily. Government also should make some policy on using mobile technology by the younger citizens.
\end{abstract}

CBMJ 2020 July: vol. 09 no. 02 P: 3-7

Key words: Sexual assaults, telecommunication, assailants, victim.

\section{Introduction}

The sexual assaults and its consequences (such as, sexually transmitted disease, teenage pregnancy, abortion, suicide etc.) are in alarming and serious public health problems around the world, especially in developing or under-developed countries. The situation is worsening day by day with the rise of communication technology. Last decades, development in communication technology has developed enormously in Bangladesh.

According to a report by Bangladesh Mohila Parishad (a Non-Government Organization working on women's human rights), the number of rape incidence was 731 from January to June 2019, while the incidence was 942 in 2018 in Bangladesh. There were 592 females were raped, 113 were gang raped, 26 were killed after being raped, and 123 were victims of attempted rape happened in said six months of 2019. ${ }^{1,2}$ Development in telecommunication raised dramatically in last decades in Bangladesh. A Bangladesh Telecommunication Regulatory Authority (BTRC) report stated that the number of mobile phone connection has reached 164.17 million at the end of October 2019. Of which, about 90 million are regular internet users. ${ }^{3}$ As people increasingly use social networking services and mobile phone technologies to communicate and socialize with each other, their use as vehicles for the perpetration of sexual assault is becoming an issue of significant concerns. This concern relates partly to the way in which such technology opens avenues for sexual victimization. It also relates to a lack of understanding among some groups

1. Dr. Iffath Farooqui, Assistant Professor of Forensic Medicine, Sylhet Women's Medical College.

2. Dr. Md. Shamsul Islam, Assistant Professor of Forensic Medicine, MAG Osmani Medical College, Sylhet.

3. Dr. Rahat Amin Chowdhury, Assistant Professor of Neurology, Sylhet Women's Medical College

4. Dr. ATM Hasibul Hasan, Assistant Professor of Neurology, National Institutes of Neurosciences, Dhaka.

Address of correspondence:

Email: iffath.swmc@gmail.com

Mobile: +8801737205047 
about how these technologies work, what exactly the nature of the problem is and what solutions are required to address perpetration and its impacts. ${ }^{4,5}$

A number of cases have been recently reported in which mobile phone and online communication technologies are connected in sexual abuse victimization in our country. Few researches observed on it and till now no research done in Bangladesh. Hence this study is carried out to evaluate the mode of communication between the assailants and the victims in cases of sexual assault.

\section{Methodology:}

This descriptive cross-sectional study was conducted in the Department of Forensic Medicine in Sylhet MAG Osmani Medical College. Data collected from the registry of "One-Stop Crisis Centre" of Sylhet MAG Osmani Medical College Hospital, where sexually assaulted victims were brought for medico-legal examination during the period of January 2019 to June 2019. Every victim was examined individually by specialists and their trainee postgraduate students of Forensic Medicine. The data from the registry book was rechecked and recorded in a standard data collection form. Professional standards and confidentiality of the data was strictly maintained. Data was analyzed using Microsoft Excel Software. Descriptive statistics was used. Ethical approval was obtained from the institutional ethics committee.

\section{Results:}

There were 87 sexually assaulted victims brought to this institution for medico-legal examination during this period. All of them were female; age ranging from 6 years to 40 years, mean age was 15.67 ( \pm 6.69) year. Age distribution of the victims showed in Table 1. Maximum victims 33 (37.93\%) lies within $11-15$ years age group. All the victims observed in this study were female. Regarding monthly income of the victim's families (Figure 1), maximum number of victim's monthly income had 20,00125,000 taka/month $(23,26.44 \%)$ followed by
$15,001-20,000$ taka/month $(19, \quad 21.84 \%)$, $>25,000$ taka/month $(18,19.79 \%), \quad<10,000$ taka/month $(15,17.24 \%)$ and $10,000-15,000$ taka/month (12, 13.79\%).

Table 1: Demographic data of the victims.

\begin{tabular}{|l|r|c|}
\hline \multicolumn{1}{|c|}{ Age of victims } & Number & $\%$ \\
\hline 6 to 10 & 17 & 19.54023 \\
\hline 11 to 15 & 33 & 37.93103 \\
\hline 16 to 20 & 27 & 31.03448 \\
\hline$>20$ & 10 & 11.49425 \\
\hline Total & 87 & 100 \\
\hline Financial status of victim's family & & \\
\hline$<10,000$ tk/months & 15 & $17.24 \%$ \\
\hline $10,000 \quad-15,000$ tk/month & 12 & $13.79 \%$ \\
\hline $15,001 \quad-20,000$ tk/month & 19 & $21.84 \%$ \\
\hline $20,001 \quad-25,000$ tk/month & 23 & $26.44 \%$ \\
\hline$>25,000$ tk/month & 18 & $19.79 \%$ \\
\hline
\end{tabular}

Particulars of the mobile phone used in communication showed in Table 2. Modern smart phone was used in $77.01 \%$ cases and normal phone (only usable for voice call and SMS sending) used in $22.99 \%$ cases. Regarding ownership, $26.44 \%$ mobile supplied by the assailant to the victims and $45.99 \%$ mobile phone were owned by victim herself; rest mobiles belonged to the victim's friends $(16.09 \%)$, relatives $(6.89 \%)$ and parents $(4.59 \%)$. Assailant paid the phone charge in $62.07 \%$ cases, followed by parent's payment $(26.44 \%)$ and others (11.49\%). 
Table 2: Particulars of the mobile phone used in communication

\begin{tabular}{|l|c|c|}
\hline Types of phone used & Frequency & Percentage \\
\hline Normal mobile phone & 20 & $22.99 \%$ \\
\hline Smart phone & 67 & $77.01 \%$ \\
\hline Ownership of the phone used & & \\
\hline Assailant & 23 & $26.44 \%$ \\
\hline Victim & 40 & $45.99 \%$ \\
\hline Parent & 4 & $4.59 \%$ \\
\hline Friends & 14 & $16.09 \%$ \\
\hline Relatives & 6 & $6.89 \%$ \\
\hline Payment for the phone usage & & \\
\hline Assailant & 54 & $62.07 \%$ \\
\hline Parents & 23 & $26.44 \%$ \\
\hline Others & 10 & $11.49 \%$ \\
\hline
\end{tabular}

Modes of communication and methods used in communication between the assailants and the victims showed in the Figure no. 1 and 2 respectively. Writing letter as a mode of communication and using of MMS as methods of communication was absent in this study. Communication through mobile was the major mode $(37 \%)$ followed by direct verbal mode $(31 \%)$, mixed verbal and mobile (26\%) and other $(6 \%)$ in this study. Others modes of communication included broad-band based social networking system (such as Messenger, Imo, WhatsApp, Viber etc.). Major method of communication was Talking (42\%). Video chatting and SMS used in 13\% and 9\% cases respectively. Mixed method (talking, SMS and video) used in $36 \%$ cases.

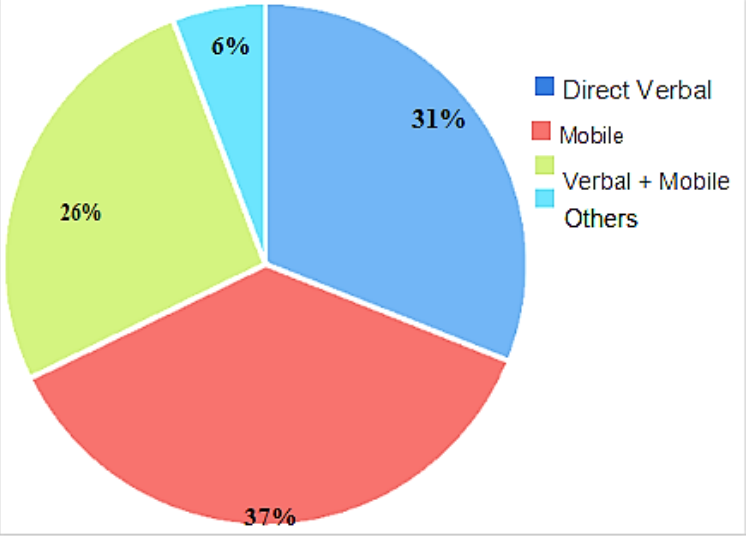

Figure 1: Modes of communication

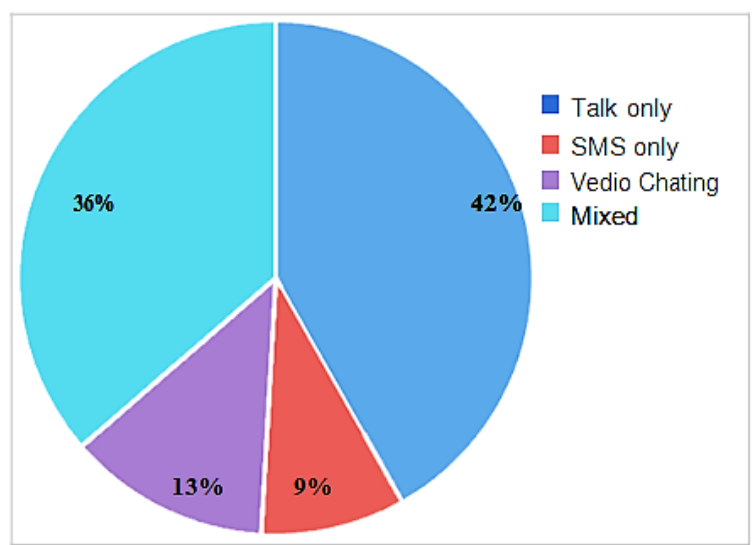

Figure 2: Methods used in communication

\section{Discussion:}

The occurrence of unwanted sexual interaction (sexual violence and sexual abuse) among young people is increasing rapidly throughout the world, especially in rapidly developing countries. Young people, particularly young women, comprise "at-risk" group for the sexual violation. ${ }^{6}$ And in most of the cases, both the offenders and the victims are known to each other. $^{7}$

It has been reported in many studies that most of the sexually assaulted victims were females. ${ }^{8-}$

${ }^{11}$ In this study, female was found to be affected in all the cases $(100 \%)$ during the study period. About $70 \%$ of the victims were of teenager age groups; mean age was $15.67( \pm 6.69)$ years. Result of our study is consistent with several previous studies. $^{7,8,10,12-14}$ In our study group, almost $80 \%$ of the victims were from low socioeconomic group. Ganguly et al ${ }^{15}$ 
reported $60 \%$ of the victims were from poor families and $43 \%$ were illiterate. Similar findings also reported by Sarkar et al. ${ }^{7}$ Smart phone was used in maximum cases $(77.01 \%)$ observed in this study. Smart phone of variable quality and price are easily available now-a-days. So that, people with low socioeconomic status also able to buy easily those mobile, and gift to those teenagers to convince them initially. In this study, victims owned mobile set was in $45.99 \%$ of cases, those were gifted by their parents or they bought themselves by saving money of their daily expenses. Assailant also gifted mobile set to victims in about one fourth of cases (26.44\%). Verbal communication (either direct or via mobile phone) was the commonest communication method used. Perpetrator of victim's own family member or close relatives are usually communicating through direct verbal way. Communication method between the victims and the assailant was talking in $42 \%$ cases, using SMS in $9 \%$ cases and performing direct video chatting in $13 \%$ cases; MMS is almost obsolete in this present time. Cost of mobile phone charge as well as internet using is very low in Bangladesh. Moreover, mobile companies provide different low-cost package talk-time and/or internet for using different social networking site regularly (especially for the night times), which further tempting such teenager girls to make new friends from unknown area. Assailants use this way to communicate with victims initially and the fate of such relationship ends with a kind of sexual assault. Therefore, parents should be careful about their children of using mobile phone, especially in using smart phone from where they have that. Educating parents as well as young users about the threats of sexual assaults and other criminal offenses through mobile phones would be worth fully. Every parent should carefully monitor when their children are using social site in mobile phone, especially about their friend list as it makes them more comfortable to come in contact with strangers. At the same time health education targeted on vulnerable groups regarding sexual behavior, legal aspects of sexual and partner relationship in an organized way is important for primary prevention of sexual assaults.

\section{Conclusion}

It appears that the unhindered access to mobile phones by the young individuals and technological advancements in the mobile telephony had facilitated the commission of sexual offences. The parents and guardians should be extra vigilant about the unfettered usage of mobile phones by the youth. Both the government and mobile networking companies should rethink about usage of mobile phone (especially smart phone) by teenagers.

\section{References:}

1. Tribune Desk. A shocking 731 rapes reported in first six months of 2019. Dhaka Tribune [newspaper on the Internet] 2019 July 8 [cited 2019 December 18]. Available from: https://www.dhakatribune.com/bangladesh/ nation/2019/07/08/a-shocking-731-rapesreported-in-first-six-months-of-2019.

2. Star Online Report. 731 women raped in 6 months. The Daily Star [newspaper on the Internet]. 2019 Jul 8 [cited 2019 Dec 18]. Available from : https://www.thedailystar.net/ country/731-women-raped-in-bangladesh-in6-months-1768477.

3. Bangladesh Telecommunication Regulatory Commission. Mobile Phone Subscribers in Bangladesh October. Available from: www.btrc.gov.bd/content/mobile-phonesubscribers - bangladesh - october 2019[Accessed 18th December 2019].

4. Quadra A. Online communication technologies and sexual assault. ACSSA aware. 2010; 25:15-19. Available from: http://www.aifs.gov.au/acssa/pubs/newsletter / n25/n25-2.html[Accessed 18th December 2019].

5. Choo KKR. Online child grooming: $A$ literature review on the misuse of social networking sites for grooming children for sexual offences Canberra: Australian Institute of Criminology, 2009. 
6. Colombage SM, Dassanayaka PB, Waidyaratne $D L, A$ study on child abuse in Anuradhapura, Colombo South and Ratnapura. 2005.

7. Sarkar S, Sharma R, Bhardwaj D, Dogra T. A study on victims and accused of sexual offences in South Delhi. Indian Journal of Forensic Medicine \& Toxicology. 2010; 4:903.

8. Kathleen C. Basile and Sharon G. Sexual Violence Victimization of Women: Prevalence, Characteristics, and the Role of Public Health and Prevention. Smith American Journal of Lifestyle Medicine. 2011; 5: 407.

9. Hwa HL, Chen SC, Wu M, Shun CT, Liu SK, Lee JC, Chn YC. Analysis of cases of sexual assault presenting at a medical center in Yaipei, Taiwan. Taiwanese Journal of Obstetrics \& Gynecology. 2010; 49(2):165169.

10. Wu $Z H$, Berenson $A B$, Wieman CM. A profile of adolescent females with a history of sexual assault in Texas: familial environment, risk behaviors and health status. Journal of Pediatric and Adolescent Gynecology. 2003;16:207-216.

11. Ingemann-Hansen $O$, Sabroe S, Brink $O$, Mpsych MK, Charles AV. Characteristics of victims and assaults of sexual violenceimproving inquires and prevention. Journal of Forensic and Legal Medicine. 2009; 16:182188.

12. Kilpatrick DG, Edmunds CN, Seymour AK. Rape in America: A Report to the Nation. Arlington, VA: National Victim Center \& Medical University of South Carolina, 1992.

13. Basile KC, Chen J, Black MC, Saltzman LE. Prevalence and characteristics of sexual violence victimization among U.S. adults 2001-2003. Violence \& Victims. 2007; 22:437448.

14. Brener CD, McMahon PM, Warren CW, Douglas KA. Forced sexual intercourse and associated health-risk behaviors among female college students in the United States. Journal of Consulting and Clinical Psychology. 1999; 67:252-259.

15. Ganguly RP, Patron KK, Jha T, Bhattacharya $A R$, Sarkar D. Sexual assault and its medical, Medico-legal and Social aspects-a retrospective study. Journal of the Indian Medical Association. 2010; 108(10): 682-690. 